\title{
Probiotic Cell-Free Culture Supernatants From Kefir Grains and Inhibition of Listeria monocytogenes
}

\author{
Ligia Isoni Auad (I), Roseane Batitucci Passos de Oliveira (I), \\ Elisabeth Neumann (I), Afonso de Liguori Oliveira (I), Luiza de \\ Alcântara Moraes (I) \\ (I) UFMG - Universidade Federal de de Minas Gerais (Av. Antônio Carlos, 6627 - Pampulha - \\ Belo Horizonte - MG CEP 31270-901)
}

\section{Resumo}

Kefir is a sour fermented milk and contains a mixture of microorganisms, mainly lactic acid bacteria (LAB). LAB are able to produce a great variety of antimicrobial substances and may be a useful and effective strategy to prevent or reduce the incidence of pathogens, thus improving food safety and consumer health. With the objective of evaluating the antagonist effect on L. monocytogenes, LAB ( $\mathrm{n}=12)$ cell-free supernatants (CFS) and cellfree neutralized supernatants (CFNS) were tested, using well diffusion and microtiter plates methods. LAB (genera Lactococcus, Lactobacillus and Leuconostoc) were isolated from milk and water kefir grains and identified by PCR. Four strains of L. monocytogenes were tested (serotypes $4 a, 4 b$, $1 / 2 \mathrm{a}$ and one isolated from frankfurters). CFNS was obtained by adding $\mathrm{NaOH}$ solution $(\mathrm{pH}=6,2)$ and catalase. Both supernatants were filtered through $0.22 \mu \mathrm{m}$ pore membranes and stored under refrigeration. Nisin was used as control. CFS and CFNS tested by well diffusion method showed no inhibition against of four strains of L. monocytogenes. However, in the microtiter plate method, all strains were inhibited, until 30 hours of incubation. After this period, the inhibitory effect was no longer observed. This may be indicative of a bacteriostatic effect when compared to nisin. Leuconostoc mesenteroides $9 \mathrm{U} 2$ presented the best antagonistic effect in both supernatants. It can be concluded that strains of probiotic LAB isolated from kefir grains are potentially capable of producing substances

\footnotetext{
Referência:

Ligia Isoni Auad, Roseane Batitucci Passos de Oliveira, Elisabeth Neumann, Afonso de Liguori Oliveira, Luiza de Alcântara Moraes. Probiotic Cell-Free Culture Supernatants From Kefir Grains and Inhibition of Listeria Monocytogenes. In: Anais do $12^{\circ}$ Congresso Latinoamericano de Microbiologia e Higiene de Alimentos MICROAL 2014 [= Blucher Food Science Proceedings, num.1, vol.1]. São Paulo: Editora Blucher, 2014. DOI 10.5151/foodsci-microal-310
} 
that show inhibitory ability against L. monocytogenes growth. These results are promising, since tested supernatants showed such capacity in their crude form. Future studies should investigate the possibility of obtaining concentrates of these substances with higher inhibitory effect and possible use in foods to ensure safety.

Palavras-Chave: Bacteriocins, Kefir, Lactic acid bacteria, Listeria monocytogenes, Probiotic

Agência de Fomento: Pró-Reitoria de Pesquisa (PRPq) - Universidade Federal de Minas Gerais 